Maurer School of Law: Indiana University

Digital Repository @ Maurer Law

\title{
Clearing the Path: The Perils of Positing Civil Society in Conflict and Transition
}

Timothy W. Waters

Indiana University Maurer School of Law, tiwaters@indiana.edu

Follow this and additional works at: https://www.repository.law.indiana.edu/facpub

Part of the International Law Commons, and the Military, War, and Peace Commons

\section{Recommended Citation}

Waters, Timothy W., "Clearing the Path: The Perils of Positing Civil Society in Conflict and Transition" (2015). Articles by Maurer Faculty. 2604.

https://www.repository.law.indiana.edu/facpub/2604

This Article is brought to you for free and open access by the Faculty Scholarship at Digital Repository @ Maurer Law. It has been accepted for inclusion in Articles by Maurer Faculty by an authorized administrator of Digital Repository @ Maurer Law. For more information, please contact rvaughan@indiana.edu. 


\title{
Clearing the Path: The Perils of Positing Civil Society in CONFLICT AND TRANSITION
}

\author{
Timothy William Waters ${ }^{*}$
}

Can there be a general theoretical perspective on civil society's involvement in transitional justice? This article considers this question in its application to the Israeli-Palestinian conflict. Within the study of transitional justice and conflict resolution, civil society - a notoriously plastic concept - can be understood narrowly as rights-oriented groups working 'for' peace, but the term is equally available to describe a broader array of communities that can either promote or prevent peace and justice.

It is, in fact, quite difficult to sustain a theoretical distinction between them, because transitional justice does not escape the dictates of politics - of differing human desires expressed through power. Efforts to memorialise imply conflict over the particular memories to be privileged; claims for reparations are not only demands for justice, but for material redistribution that in turn may promote conflict. A narrow view of civil society problematically assumes we even know - let alone agree on - what constitutes positive change.

In the context of the Israeli-Palestinian conflict, that is a fraught proposition. Both an accurate definition of civil society and the valence of justice work slip beyond the narrow confines of the received model's assumptions: both Jewish and Palestinian groups mobilise a spectrum of resources from political engagement, to overseas support, to violent self-help. On both sides, civil society groups are instrumentalised to advance not an agenda of peace or justice in some abstract sense but a parochial claim that, seen from the other side, is, in fact, an obstacle to resolution. Indeed, there may be no peace or justice initiatives that can be analytically separated from efforts the purpose and effect of which is the very opposite of our conventional understanding of the field. The range from vocal activism to violent action, the spectrum of activation, commitment and radicalism, must be understood as fraught but connected and unbroken - as, at most, a kind of punctuated continuum.

The real work performed by civil society in promoting agendas of peace and justice cannot properly be understood without locating it in a defensible theoretical and empirical framework. Imagining a narrow civil society risks skewing our analysis of what civil society can do and actually does in relation to confict. Civil society can clear the path to peace, or can provide the principal obstacles to it -it can simultaneously do both. In this it very much shares the ambiguous, multivalent profile of its classic counterpart: politics in the public sphere.

Keywords: transitional justice, peace, civil society, Israel, Palestine

\section{INTRODUCTION}

Can there be a general theoretical perspective on civil society's involvement in transitional justice? This article considers that question and applies it to the Israeli-Palestinian conflict, which tends to confirm that we have unhelpfully narrowed the concept of civil society to a contingent,

* Professor of Law and Associate Director, Center for Constitutional Democracy, Indiana University Maurer School of Law. Thanks to the audience at the Conference on Civil Society and Transitional Justice, The Minerva Center, The Hebrew University of Jerusalem, May 2014, and to Professor Clifford Bob, Professor Jeffrey Isaac, Professor Robert Ivie and Michael Szporluk for comments on earlier drafts. tiwaters@indiana.edu. 
ideologically preferential sub-set; this narrowing distorts analysis of what civil society's advocacy is in fact doing, of what it can and cannot do.

This article first reviews the dominant definitions of civil society, showing their conceptual profligacy and the heuristic reductions commonly applied to those definitions to make them manageable - assumptions that civil society is properly understood as a discrete set of mostly nonprofit organisations oriented towards a defined sense of the public good. It then critiques these assumptions - showing their historically contingent nature and reliance on arbitrarily narrow distinctions, their ethical valence combined with an ethos of apolitical virtue - especially as they are applied to the field of transitional justice and peace work, where it is frequently assumed that civil society is working 'for peace'.

The article then applies these general observations to the particular case of the IsraeliPalestinian conflict. The actual structure, attitudes and activities of groups active in the region do not match the received model's narrow assumptions about political orientation, attitudes to democracy and violence, or the purposes of peace work and transitional justice. There is no neutral, objective, unitary position that defines civil society or its work.

The article concludes by noting the analytical and practical consequences of failing to adopt a definition of civil society that follows the contours of actual experience: excessive optimism about the benefits of supporting 'civil society', yet also a risk of underestimating the power of civil society, since only its progressive elements - which are weak in Israel and Palestine are measured, while illiberal elements of civil society are ignored or discounted. Understanding in full the work civil society does requires a complete theoretical framework that is responsive to real conditions; narrowing the definition we deploy to make it accord with one's politics and one's preferences risks blinding us to how civil society actually shapes claims about war, peace and justice.

\section{Civil Society's Plasticity, and its Reductions}

... the Cartographers Guild struck a Map of the Empire whose size was that of the Empire, and which coincided point for point with it ... that vast Map was Useless ...

Suárez Miranda ${ }^{1}$

Civil society is a notoriously plastic concept, encompassing almost the entire spectrum of human social experience between the individual and family at one end and the state at the other. ${ }^{2}$

\footnotetext{
${ }^{1}$ Suárez Miranda, Viajes de varones prudentes, Libro IV, Cap. XLV, Lérida, 1658; id est Jose Luis Borges, 'On Exactitude in Science', Collected Fictions (Andrew Hurley tr, Penguin 1999) (Jose Luis Borges, 'Del rigor en la ciencia', El Hacedor (1960) 45: '... los Colegios de Cartógrafos levantaron un Mapa del Imperio, que tenía el Tamaño del Imperio y coincidía puntualmente con él ... ese dilatado Mapa era Inútil ...').

${ }^{2}$ Nicos Mouzelis, 'Modernity, Late Development and Civil Society' in John A Hall (ed), Civil Society: Theory, History, Comparison (Polity Press 1995) 224, 225 (noting that civil society '[1]ike all key concepts in the social sciences ... has a variety of meanings').
} 
Historical and contemporary accounts of civil society are broad-ranging - from Aristotle, ${ }^{3}$ to Hegel $^{4}$ (and so to Marx ${ }^{5}$ ) and Toqueville, ${ }^{6}$ to Gramsci ${ }^{7}$ and Putnam ${ }^{8}$ and Habermas and countless others - conceptualisations so profligate as to be utterly incapable of unitary interpretation. The concept is as honoured as it is unclear, "one of the standard points of reference in political debates which accept civil society in one way or another without really asking what the acceptance actually involves'.

Civil society also, problematically, describes both a set of practices and an aspiration - a type of social organisation and an ethical design for the good society. ${ }^{10}$ This is a Borgesian map so vast as to be almost useless, and so, not surprisingly, we find heuristic reductions populating the contemporary field, though with impoverishing consequences for our understanding of what that field actually looks like and actually does.

The first reduction is from the theoretical to the practical. Contemporary invocations of civil society often exhibit little of the philosophical richness surrounding the concept. The ethical sense is not entirely abandoned, certainly not repudiated - practitioners of civil society often understand something of the philosophy behind their quotidian work - but that sense is less explicated than atmospheric, subsumed into what is taken as its institutional expression: one starts out to promote the arts, and ends up building a museum. This is only natural, as it is hard to think

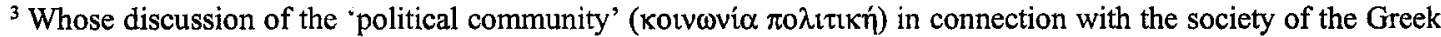
city-state is thought to be the first account of civil society: see Aristotle, Politics, (Benjamin Jowett tr, Batoche Books 1999), Bk Two, Pt 1, 22 ('Our purpose is to consider what form of political community is best of all for those who are most able to realise their ideal of life').

${ }^{4}$ The principal expositor of the individual's relation to a tripartite division of family, mediating civil society and state: see 'Georg Wilhelm Friedrich Hegel', Stanford Encyclopedia of Philosophy, 13 February 1997; subst rev 22 July 2010, http:/plato.stanford.edu/entries/hegel (Hegel's Sittlichkeit describes 'the type of sociality found in the market-based "civil society" [which] is to be understood as dependent upon and in contrastive opposition with the more immediate form found in the institution of the family ... These two opposite but interlocking principles of social existence provide the basic structures in terms of which the component parts of the modern state are articulated').
}

${ }^{5}$ Marx opposes Hegel's view of civil society as a mediating ethical space, instead seeing it as an alienating experience: see Keith Tester, Civil Society (Routledge 1992) 18 ('According to Marx, civil society is basically a terrible lie').

${ }^{6}$ See John Ehrenberg, Civil Society: The Critical History of an Idea (NYU Press 1999) xv (discussing de Toqueville's views on 'informal norms of voluntary association' and describing the dominant contemporary approach as 'a hegemonic neo-Toquevillean view among American intellectuals that civil society is a set of informal norms supporting local intermediate associations').

${ }^{7}$ In whose view civil society is a site of cultural hegemony and therefore contestation: Antonio Gramsci, Selections from the Prison Notebooks (Quentin Hoare and Geoffrey Newell Smith eds and trs, Lawrence and Wisehart 1971) 261, 271, 494.

${ }^{8}$ For whom 'the accolade civil society [is reserved] for the friendly societies and bowling leagues that only sporadically and narrowly (if at all) engage in conventional political activity': Clifford Bob, 'Civil and Uncivil Society' in Michael Edwards (ed), The Oxford Handbook of Civil Society (Oxford University Press 2011) 211. See generally Robert Putnam, Bowling Alone: The Collapse and Revival of American Community (Simon and Schuster 2001).

${ }^{9}$ Tester (n 5) 4 (continuing '[a]s such, civil society has tended to be banal or boring').

10 '[C]ivil society is complicated, most notably in being at one and the same time a social value and a set of social institutions': John A Hall, 'In Search of Civil Society' in Hall (n 2) 1, 2 (emphasis in original; also referring to 'the fuzziness of the term'). 
in purely abstract terms, and may not even be desirable; but, as we shall see, the practical turn has practical effects.

Within this move is a further reduction by institutional type. From the vast list of almost everything other than the naked individual and the state, most definitions of civil society centre on a narrower set: not-for-profit entities and informal voluntary groupings. ${ }^{11}$ It is a reductive catalogue, a list that defines civil society as the set of civil society organisations. ${ }^{12}$

That set is still enormous, so it is useful to describe the short but significant list of organisations that civil society typically is not: not organs of the state, (usually) not for-profit corporations. ${ }^{13}$ The ethical aspect of civil society has not been abandoned, only regularised, for what by definition separates civil society organisations from all others is that civil society organisations - NGOs, mostly - exist for some ethically informed purpose.

Thus there is a further functional reduction, for those ethical purposes are of a type. Definitions of civil society generally include those organisations that work for some indeterminate set of public goods. Civil society, understood this way, fixes society's problems, acting as

\footnotetext{
${ }^{11} \mathrm{cf}$ Tester (n 5) 8 ("the label of "civil society" can be applied to all those social relationships which involve the voluntary association and participation of individuals acting in their private capacities ... to equal the milieu of private contractual relationships'). In keeping with contemporary sensibilities about civil society's locus, here (according to Wikipedia, 'Civil Society', http://en.wikipedia.org/wiki/Civil_society, 14 January 2015) is a list of institutional forms that constitute civil society:

- academia

- activist groups

- charities

- citizens'militia

- civic groups

- clubs (sports, social etc.)

- community foundations

- community organizations

- consumers/consumer organizations

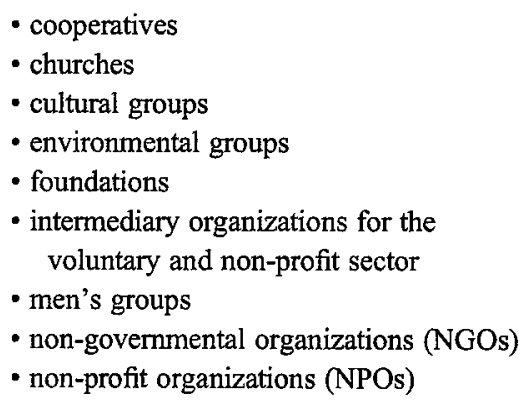

- non-profit organizations (NPOs)

- policy institutions

- political parties

- private voluntary organizations (PVOs)

- professional associations

- religious organizations

- social enterprises

- support groups

- trade unions

- voluntary associations

- women's groups
}

It is, seemingly, every kind of social organisation except for-profit companies (other than social enterprises) and the state itself.

${ }^{12}$ World Bank, 'Defining Civil Society', updated 22 July 2013, http://web.worldbank.org/WBSITE/EXTERNAL/ TOPICS/CSO/0,,contentMDK:20101499 menuPK:244752 pagePK:220503 piPK:220476 theSitePK:228717, 00.html ("The World Bank has adopted a definition of civil society developed by a number of leading research centres: "the term civil society to refer to the wide array of non-governmental and not-for-profit organizations that have a presence in public life, expressing the interests and values of their members or others, based on ethical, cultural, political, scientific, religious or philanthropic considerations. Civil Society Organizations (CSOs) therefore refer to a wide of array of organizations: community groups, non-governmental organizations (NGOs), labour unions, indigenous groups, charitable organizations, faith-based organizations, professional associations, and foundations"' (emphasis omitted)); Civicus, 'About Civicus', http://www.civicus.org/index.php/about-us-125 ('Civicus includes the following in its definition of civil society: civil society networks and organisations; trade unions; faith-based networks; professional associations; NGO capacity development organisations; philanthropic foundations and other funding bodies').

${ }^{13}$ Some definitions do include them, and certainly the classical philosophical treatments consider actors in the marketplace very much part of civil society: John Ehrenberg, 'The History of Civil Society Ideas' in Edwards (n 8) 18-23. 
watchdog of the state: competitor, complement (through public-private partnerships), or replacement. Civil society digs wells or enables others to dig their own. It advocates for improved access to courts, for organic produce, or for political change. What these activities share - what defines them and, in turn, civil society - is private action for the public good. ${ }^{14}$ Also, just as its institutional forms are defined by what they are not, so civil society's activities are usually defined by what they don't do: not make a profit (although NGOs do help to establish profitable companies and increasingly identify with profit-making social enterprises). ${ }^{15}$ Instead, civil society is marked by its civic-minded intention to do something public and good. ${ }^{16}$

Through this reduction, we approach our particular theme. In transitional justice, civil society is understood narrowly as groups working on truth projects, litigation, support for official peace or reconciliation mechanisms, and the like. Formal organisations such as the Coalition for the International Criminal Court, the International Center for Transitional Justice or Human Rights Watch, as well as informal groupings such as the Mothers of the Plaza de Mayo or the Mothers of Srebrenica, constitute the core of what we typically think of as civil society 'struggling for transitional justice'. ${ }^{17}$

\section{Who is Working 'For' Peace? The Irreducible, Intractable Politics OF CIVIL SocIETY}

[N]ow, progress is something we assume but don't analyze. This is particularly true of liberals and progressives, who, instead of subscribing to theories of change, now place their faith in an agent of change:

\footnotetext{
${ }^{14}$ The World Bank, lauding the influence of civil society, provides three examples: its 'dynamism is exemplified by successful advocacy campaigns around such issues as banning of land mines, debt cancellation, and environmental protection': World Bank (n 12).

${ }^{15}$ See, eg, 'What is the Relationship between Social Enterprise and Civil Society?', NCVO UK Civil Society Almanac, http:/data.ncvo.org.uk/a/almanac 14/what-is-the-relationship-between-social-enterprise-and-civil-society-2 (noting that '[m]uch like civil society, while there is agreement about the concept, there is less consensus about how to precisely define it. Suggested definitions cover a wide range of attributes - from whether organisations identify with the term social enterprise, to their profit distribution, to the income they generate from trading. Some characteristics are easy to measure using available data - profit distribution - but others are more difficult and require judgement on an organisation's values and objectives'); Alex Nicholls, 'Social Enterprise and Social Entrepreneurs' in Edwards (n 8) 80, 80-92; 'Research on the Emerging Model of Social Enterprise', UCLA Luskin School of Public Affairs, Center for Civil Society, http://www.civilsociety.ucla.edu/scholars/research-emerging-model-social-enterprise (arguing that owing to the decline in corporate philanthropy, '[t]he dominant paradigm by which citizen groups and other forms of grass-root activity organize to deal with a community problem and are funded by philanthropy will have to be modified or at least supplemented by other paradigms. These will include greater reliance on selfgenerated income and new hybrid organizational forms that combine a social mission with commercial entrepreneurship ... It is expected that social enterprises will expand in the coming years because of the changing economic and political environment').

${ }^{16}$ In this, civil society is, if imperfectly, different from the arts, which may be intensely private, and which are not principally or necessarily concerned with the improvement of society as such. However, supporting the arts - as opposed to artistic production per se - can be one function of civil society.

${ }^{17}$ Text of the Call for Papers, Third Annual Minerva Jerusalem Conference on Transitional Justice, 'Transitional Justice and Civil Society - Learning from International Experience', The Minerva Center, The Hebrew University of Jerusalem, November 2013.
} 
international civil society, which they believe to be a force that will end war and oppression and usher in a new and just world.

Walter Russell Mead ${ }^{18}$

... sie ist zum Geist der bürgerlichen Gesellschaft geworden, der Sphäre des Egoismus, des bellum omnium contra omnes. Sie ist nicht mehr das Wesen der Gemeinschaft, sondern das Wesen des Unterschieds.

$\operatorname{Karl} \operatorname{Marx}^{19}$

These heuristics promise to help us make sense of the sprawling world beyond the family and below the state, but in fact they may not do much conceptual or practical good, for they subdivide that non-individual, non-official universe in ways that do two unhelpful things. The standard view at one and the same time so narrowly defines civil society as to exclude actors and activities that are quite similar; yet also, by positing civil society with a uniform sense of purpose, it fails to account for diversity, contradiction and contestation even within its own narrowly defined field. ${ }^{20}$ The heuristic reduction of civil society to a world of progressively oriented NGOs thus introduces two conceptual confusions: that civil society is per definitionem composed only of those groups working for the public good; and that there is even a unified, non-ideological concept of the good - here, a just peace west of the Jordan - towards which to work.

\subsection{Civil Society's Actors are too Narrowly Defined}

The institutional reduction denies the real overlap between the actors we call civil society and other institutions. Profit-making corporations clearly occupy part of the space between family and state, and frequently engage broader questions of governance and social policy, while NGOs actively seek funding from profit-making corporations and their foundations - a 'convergence of functions and approaches [that] belies any sharp division'. ${ }^{21}$ None of this would surprise early modern theorists like Adam Smith or Hegel, whose notions of civil society assumed its close relationship with the market; ${ }^{22}$ yet standard contemporary categorisations of civil society routinely exclude this kind of private activity.

\footnotetext{
${ }^{18}$ Walter Russell Mead, 'Peace Out: Why Civil Society Cannot Save the World', Foreign Affairs, Nov-Dec 2012, http://www.foreignaffairs.com/articles/138179/walter-russell-mead/peace-out.

${ }^{19}$ Karl Marx, 'Zur Judenfrage' in Deutsch-Französische Jahrbücher (1844), http://de.wikisource.org/wiki/ Zur_Judenfrage. The 'sie' refers to religion ('It [religion] has become the spirit of civil society, the sphere of egoism, the bellum omnium contra omnes. Its essence is no longer in community but in difference': Karl Marx, 'On the Jewish Question' in David McLellan (ed and trans), Karl Marx, Early Texts (Basil Blackwell 1971) 95 (emphasis in original)).

${ }^{20} \mathrm{cf}$ Bob (n 8) 213 (noting 'two misconceptions: that civil society speaks or potentially can speak with one voice; and that this voice resounds in a left-leaning key').

${ }^{21} \mathrm{cf}$ ibid 212 ('Some civil society devotees contrast the business world's competitive, profit-seeking activities with the harmony, sympathy, and cooperation supposedly prevailing in the voluntary sector. But this distinction is overdrawn. Most non-profit organizations ... inhabit their own Darwinian worlds, vying for members, funding, and recognition. Many are also highly professionalized bureaucratic institutions ... have opened their own profitmaking ventures ... rely on corporate ... largesse ... [and] like businesses, engage in political advocacy').

${ }^{22}$ Ehrenberg ( $\mathrm{n}$ 6) xiii (surveying modern civil society theorists, and arguing that in conditions of modernity, '[c]ivil society was no longer understood as a universal commonwealth but came to mean private
} 
Similarly, the distinction between civil society and the state is overwrought. The modern bureaucratic-administrative state, with its proliferating agencies and mandates, is active in the same fields as civil society organisations as actor and facilitator. Much civil society funding comes from states or from interstate and suprastate organisations controlled by them, while the phenomenon of 'public-private partnerships' represents both the retreat of the state from postwar dirigisme and proof of its entwinement with the notionally separate, mediating sphere of civil society. ${ }^{23}$

Also, focusing on voluntary organisations denies the broad space occupied by ascriptive social identities, such as tribes or religious communities; yet excluding their often non-voluntary associations 'entail[s] missing much of the civil society activity in developing contexts'. ${ }^{24}$

\subsection{Civil Society's Definition has an Ethical Valence (Which It Denies)}

However, it is the ethical reduction of civil society - its analytical orientation towards groups working for a particularly defined idea of the public good - that is most problematic, denying the reality of how human collectives work, by similar means, towards radically different ends.

First, this reduction has a political valence. Definitions of civil society are commonly oriented towards progressive values, often assumed to be especially compatible with democracy. Missing are those groups which, though institutionally homologous and equally oriented towards the public sphere, are illiberal. ${ }^{25}$

Even when heterogeneity is tacitly acknowledged, we still find assumptions about an underlying unity of purpose, assumptions made coherent only by excluding the challenges posed by more radical diversity. In one study addressing civil society work in peace building, civil society did not include '[p]eople or groups making financial profit from the armed conflict', 'radicalized sectors of society' and anyone involved in violence - these were 'external pressures and constraints' that 'represent considerable practical and political risk to unarmed groups of civilians promoting peace' ${ }^{26}$ 'Radicalized sectors' are presumably elements of civil society with different politics.

Second, this politicised definition is infused, curiously, with an ethos of apolitical purity. In this the self-image of civil society closely tracks its close cousin, human rights, commitment to

property, individual interest, political democracy, the rule of law, and an economic order devoted to prosperity').

${ }^{23}$ Raffaele Marchetti and Nathalie Tocci, 'Conflict Society and Human Rights: An Analytical Framework' in Raffaele Marchetti and Nathalie Tocci (eds), Civil Society, Conflicts and Politicization of Human Rights (United Nations University Press 2011) 47, 50-51 (discussing the outsourcing of state services to NGOs).

24 ibid 50. See also Neera Chandhoke, 'Civil Society in India' in Edwards (n 8) 171, 177-78 (discussing the place of involuntary organisations in the definition of civil society).

${ }^{25}$ See Bob (n 8) 209-19 (criticising the definitional distinction between civil and uncivil groups, and noting (at 209) that the term uncivil society 'is used to place organization, goals, or tactics beyond the political pale'). ${ }^{26}$ Celia McKeon, 'Civil Society: Participating in Peace Processes' in Paul van Tongeren and others (eds), People Building Peace II (Lynne Rienner 2005) 567, 573 (but also noting that 'civil society also faces its own internal challenges[:] ... the heterogeneity of what is termed "civil society": the diverse array of interests, groupings and agendas that are intrinsic to any large mass of people'). 
which is seen 'as part of belonging to the modern world, but coming from some place outside political choice, from the universal, the rational, the civilized' ${ }^{27}$ It is difficult to explain the rapid rise in the prestige and power of civil society networks ${ }^{28}$ - and especially of 'civil society' as a shibbolethic proxy for democratic participation, despite NGOs' own lack of democratic legitimacy or formal representativeness - without this sense of righteous neutrality. ${ }^{29}$ Many civil society activists are fully aware of the political nature of their work. Yet, simultaneously, there persists this curious definitional blind spot - a belief, however implausible, that civil society's work somehow represents a vision of common good beyond politics: a neutral, postideological project of the rule of law. We might call this the received model.

The model was received in a particular time and place. It has an Atlanticist provenance, part of the post-Cold War Washington Consensus: an export no one would recognise inside the United States. ${ }^{30}$ Its Atlanticism suggests a related, third quality: the historically contingent nature of civil society's association with progressive values. Although the dominant view sees the relationship of civil society and progressivism as natural, counter-narratives drawing on the interwar period demonstrate how, in a variety of European states, civic associations were instrumental in shifting politics to the radical right. ${ }^{31}$ There is ample evidence that right-wing groups have long organised in ways indistinguishable from progressive civil society in all respects save ideology. ${ }^{32}$

${ }^{27}$ David Kennedy, The Dark Sides of Virtue: Reassessing International Humanitarianism (Princeton University Press 2004) 21. of Thomas Carothers and Saskia Brechenmacher, Closing Space: Democracy and Human Rights under Fire (Carnegie Endowment for International Peace 2014) 27 (civil society had 'a pleasing, nonideological quality, several steps removed from the dirty give-and-take of partisan politics').

${ }^{28}$ On networks, see Margaret E Keck and Kathryn Sikkink, Activists Beyond Borders: Advocacy Networks in International Politics (Cornell University Press 1998).

${ }^{29}$ One could find no better example of the admixture of politicisation and 'apoliticalness' than Sartre's statement about the Vietnam-era Russell Tribunal, cited in its more recent incarnation as a people's tribunal on Israel's occupation: 'The legality of the Russell Tribunal comes from both its absolute powerlessness and its universality': Jean-Paul Sartre, 'Inaugural Statement at the Russell Tribunal on Vietnam, 1967' in 'Findings of the Final Session of the Russell Tribunal on Palestine', Brussels (Belgium), 16-17 March 2013, http://www.russelltri bunalonpalestine.com/en/full-findings-of-the-final-session-en. In less charged contexts, the apolitical view can achieve an almost touching banality: see Sungho Kang, John W McDonald and Chinsoo Bae, 'Introduction' in Sungho Kang, John W McDonald and Chinsoo Bae (eds), Conflict Resolution and Peace Building: The Role of NGOs in Historical Reconciliation and Territorial Issues (Northeast Asian History Foundation 2009) 11, 17 ('Transnational NGO Networks are trying to live up to the universal values and people-centered norms, being free from exclusive national interests and authorities').

${ }^{30}$ There, it is a given that civil society actors - otherwise known as special interests and activists - advance preferential political agendas: the NRA and Planned Parenthood are clearly examples of civil society, and equally clearly partisan. Thomas Carothers made this point recently at a lecture at Indiana University: see also Carothers and Brechenmacher (n 27) 55.

${ }^{31}$ This occurred at a time when democratic institutions were weak, but there is no reason to think this is a necessary condition; the recent rise of the illiberal right in Hungary has been driven by civic organisations which have flourished in a stable, institutionalised democracy: see Virág Molnár, 'Civil Society, Radicalism, and the Rediscovery of Mythic Nationalism', presented at the 19th World Convention, Association for the Study of Nationalities, Columbia University, 26 April 2014 (discussing recent Hungarian events and illiberal civil society during the interwar period).

${ }^{32}$ See generally Clifford Bob, The Global Right Wing and the Clash of World Politics (Cambridge University Press 2012). Nor do civil society organisations necessarily model liberal and democratic virtues in their internal process; 'indeed, some would argue that the most nimble and effective organizations are almost Leninist': Bob (n 8) 213. By contrast, illiberal organisations can be internally democratic and participatory. 
In other words, civil society's dominant ethical orientation may be nothing more than an artefact of late twentieth century politics: an over-generalisation from the conditions of the late Cold War and the unipolar moment of the 1990s, when civil society happened to take liberal forms and authoritarian regimes transitioned towards democratic institutions modelled on Western practices. ${ }^{33}$ There is no reason to believe that those tendencies obtain at all times and in all places especially areas marked by protracted conflict that differ from the stable political settings in which the contemporary model was first articulated. ${ }^{34}$

So the ethical valence of the received definition is narrow, and tilts left. But it is, in fact, quite difficult to sustain a theoretical distinction between the advocacy work of progressive civil society organisations and the act of lobbying more generally - an act which, in other contexts, we readily recognise can be aimed at preventing positive change, as well as encouraging it.

\subsection{Transitional Justice does not Escape Politics}

This is surely doubly true for the field of transitional justice. Indeed, while these concerns about definition and the masking of political preference are general, if there is an area of civil society activity that is least plausibly apolitical, it is surely justice and peace work. While one might imagine an immunisation campaign, or even election monitoring, as non-political,,$^{35}$ there is no way to describe the purpose and activities of transitional justice like that: by its nature, transitional justice engages with the troubled politics of a past regime, and therefore with the politics of the present.

The political nature of transitional justice may not be immediately apparent in the work of civil society - documenting, litigating, monitoring, educating, calling for reparations, commemorating and memorialising events and victims, both in past and ongoing conflicts ${ }^{36}$ - marked as it is by its triple foci on truth, healing and legality. Thus documenting past violations is seen as neutral truth telling, an exercise in objective historical scholarship; providing therapy for victims of torture is seen as a medical act, or one of human charity; and formal mechanisms to evaluate and punish wrongdoers may, in asserting the rule of law, seem the very antithesis of politics.

\footnotetext{
${ }^{33}$ See Carothers and Brechenmacher (n 27) 22-23; Marc Morjé Howard, 'Civil Society in Post-Communist Europe' in Edwards (n 8) 134, 134 (noting that the transitions in Eastern Europe were 'the source of the revitalization of the term "civil society" itself. Indeed, had it not been for Solidarnosc ... and the subsequent "people's revolutions" ... the term civil society would almost certainly not have become so widely used by academics or policy makers').

${ }^{34} \mathrm{cf}$ Marchetti and Tocci (n 23) 48-51 (and arguing (at 49) that civil society operates differently in conflict societies, producing 'a wide range of civil society actors, including both "civil" and "uncivil", carrying out a wide range of actions').

${ }^{35} \mathrm{cf}$ Carothers and Brechenmacher (n 27) 18 ('International assistance to help strengthen party development in transitional countries has always been an especially sensitive area of democracy and rights work, for understandable reasons - it is easy for citizens of the country to interpret outsiders' work with political parties as efforts to favor certain parties and thereby influence electoral outcomes'), and 54-55 (discussing the political effects of notionally neutral party aid). Immunisation campaigns in Pakistan and West Africa have become a source of suspicion about Western intervention.

${ }^{36}$ The list is drawn from the sample topics in the text of the Call for Papers, Conference on Civil Society and Transitional Justice, The Minerva Center, The Hebrew University of Jerusalem, May 2014.
} 
However, transitional justice work does not escape the dictates of politics - which is to say, of differing human desires expressed in power. Efforts to memorialise imply struggle over the particular memories to be privileged; reparations are not only demands for justice, but for material redistribution that in turn promotes conflict; lustration and prosecution are not only about reasserting law, but asserting power. A narrow view of civil society problematically assumes we even know - let alone agree on - what constitutes positive change.

Furthermore, just as the general view of civil society exhibits bias, so too the received image of transitional justice has a restrictive valence. The standard assumption - so standard as to be nearly invisible - is that justice occurs during transitions from repressive regimes to democratic regimes - not the other way round.$^{37}$ Yet, a cursory glance at history shows many of the same techniques - trials, truth commissions, lustration, history and memory projects - deployed in transitions to repression. ${ }^{38}$

Thus, when we think about civil society in relation to a field like transitional justice, we think first of rights-oriented groupings like the Coalition for the ICC, or of groups working 'for peace'; but the category is equally available to describe a broader array of groups active in ways that either promote or prevent peace, and that advance mutually incompatible claims about justice. ${ }^{39}$ Let us now see how these general ideas play out in the specific context of peace-making and transitional justice west of the Jordan River.

\section{Weaponising Civil Society: Parochial Peace(s) in Israel and Palestine}

$[\mathrm{H}]$ ow does one determine that a given action undertaken by civil society actors is a step towards peace? Which definition of peace?

Laure Fourest ${ }^{40}$

Indem die Besonderheit an die Bedingung der Allgemeinheit gebunden ist, ist das Ganze der Boden der Vermittlung, wo alle Einzelheiten ... sich frei machen, wo die Wellen aller Leidenschaften ausströmen, die nur durch die hineinscheinende Vernunft regiert werden.

GWF Hegel ${ }^{41}$

\footnotetext{
${ }^{37}$ The valence is apparent in the title of one of the most prominent texts in the field: Neil Kritz (ed), Transitional Justice: How Emerging Democracies Reckon with Former Regimes (United States Institute of Peace 1995).

${ }^{38}$ I recently heard a presentation on the Hungarian White Terror, following the Tanácsköztársaság (Hungarian Soviet Republic) of 1919, which referred to its denunciations, trials and purges as 'transitional justice': Emily Gioielli, 'Burning out this Nest of Serpents: Counter-Revolution in the Hungarian Domestic Sphere, 19191922', presented at the Midwest Slavic Conference, Ohio State University, 29 March 2014. However, this is rare - a divergence from the restrictive vocabularies of the discipline.

${ }^{39} \mathrm{cf}$ Marchetti and Tocci (n 23) 52 ("Considerable attention has been devoted to global civil society and transnational social movements ... role in preventing and resolving war; yet insufficient attention has been devoted to the role of local civil society in conflict creation') (citations omitted).

${ }^{40}$ Laure Fourest, 'Human Rights, Civil Society and Conflict in Israel/Palestine' in Marchetti and Tocci (n 23) 75, 78 79.

${ }^{41}$ GWF Hegel, Grundlinien der Philosophie des Rechts oder Naturrecht und Staatswissenschaft im Grundrisse (Zusatz), in GWF Hegel, Werke (Band 7) 340 para 182 (Suhrkamp 1989) ('Since particularity is inevitably conditioned by universality, the whole sphere of civil Society is the territory of mediation where there is free play for
} 


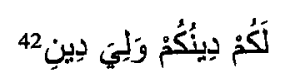

In the context of the Israeli-Palestinian conflict, these two problematic propositions - that civil society is somehow working 'for peace', and that peace is a unitary, even objective or neutral aspiration - are especially fraught. Mapped against the actual behaviour of groups active in the region, a proper definition of civil society and of the valence of justice work must move beyond the confines of the narrow assumptions of the received model.

\subsection{Israeli Civil Society Reductions: Left Peace-building, and Everything Else}

There are ready examples of Israeli groups whose work on peace and transitional justice conform to the dominant view: the human rights group B'Tselem; Breaking the Silence, which collects testimonies about the occupation from Israeli soldiers; Gisha, which focuses on freedom of movement; the Israeli Committee against House Demolitions; or Ittijah and Adalah working on behalf of the Palestinian Arab minority within Israel. ${ }^{43}$ Some of these groups work on intercommunal dialogue or action with groups in the West Bank, although this has become more strained over the last decade. ${ }^{44}$

Of course, these examples are not the whole field. Yet they might appear to be, for looking at how civil society in the region is analysed, we find many of the same narrowing reductions applied. We find assumptions that civil society naturally promotes peaceful cooperation ${ }^{45}$ and that a human rights orientation is politically neutral ${ }^{46}$ we find also the categorical exclusion of illiberal or rightist organisations. Thus a directory of peace-building organisations in IsraelPalestine 'focuses only on those organizations working for peace across the divide'; ${ }^{37}$ listing

every idiosyncrasy ... and where waves of every passion gush forth, regulated only by reason glinting through them': GWF Hegel, Elements of the Philosophy of Right, Third Part: Ethical Life, ii, 'Civil Society' para 182 (addition)). The translation freely mentions 'civil Society' - words not literally appearing in the excerpt, but clear from the surrounding context.

${ }^{42}$ Qur'ān 109:6, Al-Kāfirūn' (The Disbelievers) ('Unto you your religion, and unto me my religion': Marmaduke Pickthall (tr), The Meaning of the Glorious Koran (Everyman's Library and Alfred A Knopf 1992).

${ }^{43}$ On Israeli Palestinian NGOs generally, see Shany Payes, Palestinian NGOs in Israel: The Politics of Civil Society (Tauris Academic Studies 2005).

${ }^{44}$ See Fourest (n 40) 75 ('Although their fates are closely intertwined, Palestinian and Israeli civil societies have grown increasingly and dramatically oblivious to one another since the second Intifada').

${ }_{45}$ ibid 85-86 (discussing P2P programmes promoted by international donors 'based on the assumption that a better way to achieve peace was to encourage bi-communal projects that should come from the people themselves'). For an example of analysis steeped in hagiographic assumptions about unified purpose see Elise Boulding, 'Hope for the Twenty-First Century: NGOs and People's Networks in the Middle East' in Elise Boulding (ed), Building Peace in the Middle East: Challenges for States and Civil Society (Lynne Rienner 1994) 319, 319-20.

${ }^{46}$ Fourest (n 40) 79 ('In Israel, a number of CoSOs [conflict society organisations] use the human rights discourse to assert their non-political identity: they may develop worthy programmes defending human rights in the OPT [occupied Palestinian Territories], but avoid taking a clear political stand regarding the occupation, which is the primary cause of human rights violations. Here, defending human rights has sometimes become a synonym for political neutrality').

${ }^{47}$ Edy Kaufman, Walid Salem and Juliette Verhoeven (eds), Bridging the Divide: Peacebuilding in the Israeli-Palestinian Conflict (Lynne Rienner 2006) 223 (noting that only groups that provided information were included). 
some 80 Israeli, Palestinian or joint organisations, it appears not to include any right-wing organisations opposed to rapprochement. ${ }^{48}$ This self-selection is normatively coherent, but analytically deficient if one wanted a realistic directory of organisations working on, or affecting, what is commonly known as the peace process.

These reductions map a preferential sub-set of a far broader field. The organisations whose work intentionally addresses and actually affects transitional justice or peace making range far beyond an arbitrarily narrow list of progressive civil society organisations. Some of the clearest evidence of this deep heterogeneity can be found in inter-NGO disputes within Israel or between Jewish groups - disputes pitting two NGOs, each committed to peace and justice, against each other. Two examples will make the point.

\subsubsection{Human Rights Groups and Their Opponents: New Israel Fund and Im TiRTzu}

In recent years there has been increased scrutiny of and pressure on Israeli human rights groups. One episode involved the New Israel Fund, a prominent group very much of the kind typically associated with the received view of civil society. ${ }^{49}$ The way in which the episode was publicly framed demonstrates the analytical distortions that a narrow categorisation of civil society produces.

The New Israel Fund came under criticism in connection with the Goldstone report, which examined the 2008-09 Gaza offensive, with critics claiming that the Fund had indirectly supported the report. A New York Times article reporting these events relied on a construction of civil society typical of the received style, placing civil society organisations in combative

\footnotetext{
${ }^{48}$ Some articles in the volume that includes the directory explicitly note the problem and examine a broader spectrum: see, eg, Tamar Hermann, 'Civil Society and NGOs Building Peace in Israel' in Kaufman, Salem and Verhoeven, ibid 39, 39-40 ('Too often civil society experts, researchers, and activists alike have a blind spot for grassroots activities that contravene their own political preferences, which in most cases are on the liberal end of the spectrum. These analyses often try to portray unidimensional civil societies that are benign in terms of civil rights, human rights or peacemaking, while ignoring the groups that promote discrimination or racism or that oppose resolution of ethnic or national conflict'), and 45-47 (analysing the activities of right-wing NGOs in response to the Oslo process). The rightist group discussed by Hermann, Zo Artzenu, does not appear in the directory; the left-oriented groups do.

${ }^{49}$ And self-associated: its website declares it is '[w]idely credited with building Israel's progressive civil society from scratch, we have provided more than $\$ 200$ million to more than 800 cutting-edge organizations since our inception': New Israel Fund, 'FAQS', http://www.nif.org/about/faqs. The Fund does not consider itself a peace organisation, but closely aligns itself with the movement and its goals, which it identifies as progressive:

NIF is not a 'peace' organization in that we do not involve ourselves in the specifics of the ongoing peace process. Since our inception, the New Israel Fund has believed that only a just and equitable society can make peace with its neighbours. Our work for human rights, social justice and religious pluralism is the natural complement of progressive groups who are advancing the two-state solution and the peace process.
}

As a matter of policy and organizational values, NIF:

- supports an end to the occupation of Palestinian territories as a central principle of the strategic framework in which we operate;

- supports two states for two peoples and strongly advocates for efforts to realize that goal;

- opposes the settlement enterprise as inimical to the peace process and to the future of Israel as a just and democratic society. 
contradistinction to the state: in Israel '[g]overnments and the watchdog organizations that monitor them have rarely seen eye to eye' ${ }^{5}{ }^{50}$ Here the Fund is a watchdog, under pressure from the state; but, in fact, the pressure on the Fund came in considerable measure from other NGOs in particular, a media campaign launched by Im Tirtzu, 'an ultra-Zionist non-governmental organization'. ${ }^{51} \mathrm{~A}$ second group, NGO Monitor, also raised criticisms. ${ }^{52}$

The formal framing of the New York Times article is that 'human rights groups' are under pressure; this assumes a distinction between the kinds of organisation that are under pressure and other kinds, which are sources of that pressure. Thus, while the New Israel Fund is a human rights-oriented member of civil society, Im Tirtzu and NGO Monitor - each a right-wing group - are simply threats. But, of course, Im Tirtzu and NGO Monitor are part of civil society too. Im Tirtzu - whose structure ${ }^{53}$ and purpose $^{54}$ place it squarely within the category - advocates on issues closely related to the core peace process, such as the settlements and the status of Jerusalem, ${ }^{55}$ although from positions almost diametrically opposed to those of the New Israel Fund.

To be sure, these groups are also ideologically linked to Likud and other right-leaning parties now in government, but this simply exemplifies the quite typical entanglement of governmental and non-governmental organisations, a phenomenon that occurs across the political spectrum, especially in respect of funding. ${ }^{56}$ Also, Im Tirtzu is reportedly closely linked with radical settler groups - but this is the point: many of those groups are, from the received perspective, 'opposed to peace', but they conceive of themselves as civil society organisations and what they do as human rights work in the cause of peace. A directory of these groups - settler groups, such as the umbrella Mo'etzet Yesha (Judea and Samaria and the Gaza Strip Council, a successor to

\footnotetext{
${ }^{50}$ Isabel Kershner, 'Israeli Rights Groups View Themselves as under Siege', The New York Times, 5 April 2010, http://www.nytimes.com/2010/04/06/world/middleeast/06israel.html?_r=1\&.

51 ibid.

52 ibid ("'Up until now [such organisations] have enjoyed a halo effect as highly regarded human rights watchdogs," said Gerald Steinberg, an Israeli political scientist and president of NGO Monitor, a conservative watchdog group financed by American Jewish philanthropists. "They were not seen as political organizations with biases and prone to false claims"').

${ }^{53}$ Im Tirtzu describes itself as a registered association 'covered by Section 46 of the Income Tax Ordinance' with a funding relationship with the Central Fund of Israel, which has 501c3 status in the United States: Im Tirtzu, 'Frequently Asked Questions', http://en.imti.org.il/faq.html.

${ }^{54} \mathrm{Im}$ Tirtzu, 'Our Mission', http://en.imti.org.il/ ('Im Tirtzu's goal is to strengthen Zionist values in academia and in society as a whole while providing a home for students who know and truly understand that Zionism is their heritage and their birthright').

${ }^{55} \mathrm{Im}$ Tirtzu (n 53):
}

10. What is Im Tirtzu's position on the issue of the unity or division of Jerusalem?

Im Tirtzu believes it is crucial to preserve the unity of Jerusalem under Israeli sovereignty in any future political settlement ...

The issue of the unity of Jerusalem should stand above any disagreements within Israeli society and the Zionist ethos ... In the words of the late Prime Minister Yitzhak Rabin ... : '... Jerusalem is not an issue to compromise on and there is no peace without Jerusalem' (title emphasis in original)

${ }^{56}$ The directory referred to earlier appears in a volume prepared by the European Centre for Conflict Prevention, with funding from the United States Institute of Peace, Cordaid Netherlands, and the Netherlands Ministry of Foreign Affairs: Kaufman, Salem and Verhoeven (n 47) front material. 
Gush Emunim), or the Institute for Zionist Strategies - and their foreign civil society supporters would fill a book.

\subsubsection{True Zionism, True Victims: Berkeley Jewish Student Union and Breaking the Sllence}

In 2013, the Jewish Student Union of the University of California at Berkeley voted to reject membership for the university affiliate of J Street, the liberal lobbying organisation, because of its relationship with Breaking the Silence. The Student Union pointed to a bylaw prohibiting members from hosting 'speakers who demonize Israel', apparently referring to Breaking the Silence's opposition to Israel's occupation of the West Bank. ${ }^{57}$ All the actors are classic civil society organisations: a student organisation, a public interest lobby with a college affiliate, an NGO. Only their views are mutually incompatible.

Their incompatible views relate directly to interventions in the peace process and transitional justice. Tellingly, Breaking the Silence's retort criticises the Berkeley group both for distortion of true Zionist principles and a misplaced sense of victimisation: ${ }^{58}$

A blanket rejection of criticism of Israel denies Israel's responsibility for its choices and actions. This action effectively declares that Jewish victimhood persists unabated, and that the Zionist project is, therefore, a failure. Immunity to criticism is the consolation prize of victims, but Israel is a powerful country that makes free choices ... and makes mistakes from which it has the opportunity to learn. In criticizing Israel and holding it to its own values, we, the soldiers who broke the silence, are the manifestation of the Zionist dream. Thus, in its recent decision, the Jewish Student Union expressed anti-Zionist sentiments.

We are not concerned here with which organisation represents true Zionism, but rather the conflicting claims themselves. That resistance to the peace work of a civil society organisation like Breaking the Silence might be grounded on a claim of historical or continuing Jewish victimhood suggests what should be obvious: resistance to 'peace work' is itself an intervention in debates about memory, remembrance and memorialisation - which is to say, it is itself transitional justice. It is peace work too.

In these examples, the various actors all have the formal and institutional structure of conventional civil society organisations. It is their orientation and purpose that renders them, in effect, invisible as civil society, excluding them from the analytical category: not really civil society because, whatever their institutional forms, their purposes are not those of civil society, which is to work for a particularly defined public good.

\footnotetext{
${ }^{57}$ At least, this was the interpretation given by a representative of Breaking the Silence: Oded Na'aman, 'J Street $\mathrm{U}$ Rejected for Standing Behind IDF Soldiers', The Daily Beast, 11 October 2013, http://www.thedailybeast.com/ articles/2013/10/11/idf-soldiers-j-street-u-rejected-for-standing-behind-us.html; J Street $U$, http://www.jstreetu.org. 58 ibid.
} 
Sometimes this exclusion is merely implicit, but other times it is quite explicitly embraced. Referring to 'progressive' civil society, as the New Israel Fund does, acknowledges that there might be a broader civil society that is not progressive, but nonetheless focuses our attention on the sub-set - and indeed delegitimises the other actors, allowing us to believe that they are both normatively and analytically separable, when in so many things they do, they are not..$^{59}$

\subsubsection{Civll Society by Other Means: Price Tag and Violent Activism}

This suggests a second, closely related point. The range, not only of organisations and orientations, but of activities affecting peace work and transitional justice, is far broader than the conventional definition acknowledges. This is true for both sides in the dispute. Groups mobilise a spectrum of resources from monitoring, organising and lobbying, to overseas support and to violent self-help, as strategies to advance positions in the peace process, which is to say in the conflict. ${ }^{60}$

We have already considered the relationship of civil society's peace work with advocacy and foreign support. To take an example from the extreme end of the spectrum (violent action), consider one extremist group: the Price Tag movement. Tag Mechir, a movement within the West Bank settler community, seeks to extract a price for acts of Palestinians or Israelis, including their governments, that the group's members see as harmful to the settler movement; ${ }^{61}$ these include the destruction of agricultural property (such as the cutting of olive groves), arson and vandalism. ${ }^{62}$

The Price Tag groupings are outlawed - not officially defined as terrorists, but as an illegal organisation similar in nature. ${ }^{63}$ Of course, their illegality is analytically irrelevant to their civil society status - if anything, it merely helps to confirm that they are non-state actors, since clearly their actions are not state or public policies. Instead, they are a grassroots form of political

${ }^{59} \mathrm{cf}$ Marchetti and Tocci (n 23) 52 (arguing that "using the definitions "civil" and "uncivil" society would convey the false understanding that the two types of actor are easily separable').

${ }^{60} \mathrm{cf}$ Fourest (n 40) 88 (listing the types of activity in which civil society organisations involved in the conflict take part: legal action; grassroots organisations, political activism and peace advocacy, bi-communal activities, and violent action); Marchetti and Tocci (n 23) 53, Table 3.1 (listing, under activism, 'NGOs, Lobby groups, Grassroots social movements, Local communities, Combatant groups').

${ }^{61}$ Abraham Foxman, 'Israel Cannot Wait Any Longer to Crush Price Tag Attacks', Ha'aretz, 18 May 2014, http:// www.haaretz.com/opinion/.premium-1.591287 (describing the attacks as 'reprisal assaults' by 'extremist, and often young Israeli Jews ... react[ing] to any number of events - including the dismantling of illegal settlements by government officials, progress in the Israeli-Palestinian peace process and terror attacks against Israelis'). cf Jonathan S Tobin, 'The Price Tag of Palestinian Violence', Commentary, 17 April 2014, http://www.commentary magazine.com/2014/04/17/the-price-tag-of-palestinian-violence-abbas-terrorism (calling for punishment of the 'tiny group of extremists who have attacked Palestinians in what they call "price tag" attacks', but also arguing that "those who claim to constitute the "peace camp" in Israel and the United States tend to regard any attention given to Palestinian crimes as a distraction from the more important work to negotiate an agreement').

62 'Israeli Mosque Entrance Torched in Suspected Price Tag Attack', JTA, 18 April 2014, http://www.jta.org/2014/ 04/18/news-opinion/israel-middle-east/israeli-mosque-entrance-torched-in-suspected-price-tag-attack.

63 'Price Tag Attacks', Anti-Defamation League, updated 6 March 2015, http://www.adl.org/israel-international/ israel-middle-east/content/backgroundersarticles/price-tag-attacks.html (noting Defence Minister Moshe Ya'alon's announcement that "price tag attacks would henceforth be defined as "illegal organizing" and treated in a similar fashion to acts of terror' - clearly, therefore, the work of organised groups). 
engagement undertaken by communities who are at least as well organised as, say, the Mothers of the Plaza de Mayo.

Perhaps this is not a civil society movement at all? Price Tag is, at least in the eyes of its detractors, fundamentally opposed to the democratic order of Israeli society ${ }^{64}$ - but as we have seen, there is no necessary connection between support for democracy and belonging to a civil society-like organisation. One might more plausibly object that resort to violence must be excluded from any meaningful definition - and some definitions do exclude it. ${ }^{65}$ Yet there are clear traditions of civil disobedience within civil society organisations, and also of radicalisation, which should encourage us to see non-violence as a tactical alternative, an activity on a spectrum. In addition to violence, Price Tag activities also include demonstrations and road blockades - classic tactics of civil disobedience widely practised on both the right and the left. ${ }^{66}$ All of this is to say that groups such as Price Tag are plausibly a form of civil society, applying a range of techniques to affect the political process surrounding the settlements one of the core issues of the peace negotiations and of transitional justice processes, since settlements, refugees, land and sovereignty are integrally related.

If, in defining transitional justice, we focus on engagement with or the effects on the broader peace process, then oppositional work, including violence, is clearly relevant to understanding the dynamics of actors who seek to affect the outcome. Excluding such activity seems preferential - a function of ethical commitments - rather than an analytically defensible distinction. The killings in mid-2014 of three Israeli youths and of one Palestinian that precipitated Hamas rocket attacks on Israel and Israeli airstrikes and a ground offensive into Gaza - killings that were the work, apparently, of committed activists on each side - surely stretch the conception of civil society, but even more certainly have had their effects on the peace process, which no analysis could afford to ignore.

\subsection{Palestinian Reductions: Narrow Civil Society, Broad Liberation Struggle}

There are also familiar examples of civil society from Palestine: the Palestinian Center for Human Rights and al-Salah in Gaza; al-Haq and the Ramallah Center for Human Rights Studies in the West Bank. Here, too, while there are a number of NGOs in the West Bank that meet the narrow definition's criteria - as well as Israeli Arab groups, which occupy a middle position and include many of the conventional organisations working in the peace movement ${ }^{67}$ - there are many others

\footnotetext{
${ }^{64}$ See, eg, Foxman (n 61) (calling Price Tag an 'abhorrent phenomenon, which ... is antithetical to Jewish values, and stands in stark contrast to the democratic ethics on which the State of Israel was founded', and arguing that 'the vast majority of Israelis ... recognize the danger price tag attacks pose to the moral fiber of Israeli society and to the democratic and Jewish nature of the state').

${ }^{65}$ See, eg, McKeon (n 26) 567, 567-73 (identifying four roles of civil society: "advocating dialogue as an alternative to armed violence ... facilitating dialogue between the parties ... monitoring compliance and violations ... [and] participating at the negotiating table').

${ }^{66} \mathrm{See}$, eg, Hermann (n 48) 47 (discussing the invocation of Martin Luther King by right-wing group Zo Artzenu as a model for civil disobedience and the acquittal of the group's leader on free-speech grounds of charges of disrupting public order).
}

${ }^{67}$ See generally Payes (n 43). 
who do not, even though they are clearly involved in the very same set of issues. Thus, within the West Bank and Gaza, religious organisations were among those most opposed to the Oslo peace process and, as a consequence, 'Islamic groups came to represent the only credible alternative for those Palestinians who did not accept the terms of Oslo'. ${ }^{68}$ Although now in government, Hamas clearly had and retains many of the features of a popularly based civil society organisation, yet its involvement in peace negotiations is anathema to the Israeli government and much of Israeli society.

Like Jewish groups, Palestinian groups mobilise domestic and foreign resources, and we could rehearse analogous examples of intragroup conflict or resort to diverse tactics, including violence. However, the usual definitional restrictions on the range of activity thought consistent with civil society and its goals are even more difficult to map onto the known range of actors in Palestine or their attitudes. Whereas in Israel many actors openly condemn the Price Tag movement for its violence, in Palestine even groups that fit the received definition of civil society acknowledge the relevance, and relatedness, of violent struggle; the director of al-Haq, for example, has said that "civil society is against violence but we understand violent action as another way to resist. Resistance is both a right and a duty ${ }^{6}{ }^{69}$ In such a context, restricting the definition of civil society to those groups that do not use violent tactics seems arbitrary. ${ }^{70}$

Still more problematic for a narrow analysis of civil society are the actions of Palestinian NGOs that clearly fall squarely within the received definition, yet are profoundly contested. For example, a wide spectrum of recognised civil society actors in Palestine and abroad supported efforts starting in 2009 for the Palestinian Authority to join the International Criminal Court (ICC). ${ }^{71}$ An ICC bid - including a second, successful effort to accept the Court's jurisdiction $^{72}$ - is not only part of a broader strategy to assert and entrench Palestinian statehood, but also

\footnotetext{
${ }^{68}$ Fourest (n 40) 86.
}

${ }^{69}$ ibid 90.

${ }^{70}$ United Nations (UN), Division for Palestinian Rights, UN International Conference of Civil Society in Support of Israeli-Palestinian Peace, Brussels (Belgium), 30-31 August 2007, 39 (noting, in the context of a common position adopted by Palestinian civil society organisations at the 2005 Durban conference, that ' $[t]$ he ANC in South Africa had a very clear four-part strategy: to mobilize the local population for a symbolic arms [sic] struggle; a diplomatic strategy; mobilization of global civil society; and ... leadership about how each of those parts fitted together'); cf Mohammaed Abu-Nimer, 'Nonviolent Action in Israel and Palestine: A Growing Force' in Kaufinan, Salem and Verhoeven (n 47) 158-65 (discussing strategic and tactical debates among Palestinian groups concerning the use of violence).

${ }^{71}$ See, eg, Russell Tribunal (n 29) (recommending referral to the ICC, and describing itself thus: "the RToP dealt with ... violations of international law committed by Israel. It also highlighted the continuity and comprehensiveness of Israeli policy that intends, ultimately, to render impossible the establishment of a Palestinian state'); Bill van Esveld, 'Why Palestine Should Seek Justice at the International Criminal Court', Ma'an News Agency, republished by Human Rights Watch, 6 December 2013, http://www.hrw.org/news/2013/12/06/why-palestine-shouldseek-justice-international-criminal-court (discussing the politics surrounding a new application, and arguing for joining the Court to avoid 'impunity for crimes fueling [sic] further abuses', and linking this to the settlements). ${ }^{72}$ Mahmoud Abbas, Declaration Accepting the Jurisdiction of the International Criminal Court, 31 December 2014, http://www.icc-cpi.int/iccdocs/PIDS/press/Palestine_A_12-3.pdf (recognising the jurisdiction of the ICC under art 12 of the ICC Statute (Rome Statute of the International Criminal Court (entered into force 1 July 2002) 2187 UNTS 90) for crimes committed in occupied Palestinian territory since 13 June 2014); Human Rights Watch, 'Palestine: ICC Prosecutor Opens Initial Inquiry,' 29 January 2015, http:/www.hrw.org/news/ 2015/01/29/palestine-icc-prosecutor-opens-initial-inquiry. 
of an effort to advance a transitional justice agenda: one recent United Nations civil society conference discussed 'the need to take positive action to reframe the conflict while holding Israel accountable for its responsibilities under international law, and to take up the issue of war crimes'. ${ }^{73}$ Here, a peace settlement and justice claims are expressly linked.

Yet such moves are clearly seen on the Israeli side and among its international supporters as 'devastating to the peace process' ${ }^{74}$ Likewise, invocations of apartheid to describe the occupation - and related boycott and divestment campaigns - are deeply offensive to many Israelis, and generally perceived in Israel as unproductive, even though they are part of a conscious legal strategy for Palestinians. ${ }^{75}$

In a similar way, efforts to memorialise and commemorate past suffering represent core components of the praxis of transitional justice, but in the context of the Israeli-Palestinian conflict they foreground deep, often irreducible interpretive differences between two worldviews. Thus, in the early 2000s the organisation Zochrot was 'devoted to introducing the Palestinian Nakba into the discourse of Jews in Israel, in order to achieve accountability for the tragedy of 1948. This accountability is a necessary condition of reconciliation between Israelis and Palestinians' ${ }^{76}$ However, memorialisation is inextricably linked to the present, not merely as reconciliation, but as political contestation between two largely incompatible state-building projects, and as such is at least as likely to constitute an obstacle to agreement as a source of amelioration. Memorialisation is thus not merely an effort to process the past: efforts to designate 15 May 2008 'as a day of global mobilization to commemorate the Nakba, and the continuing dispossession and denial of Palestinian rights ${ }^{77}$ purposely conjoined memory and a current political dispute. ${ }^{78}$

${ }^{73}$ UN International Conference on Civil Society (n 70) 39. The UN is traditionally no great friend of Israel - the conference was organised by the 'Division for Palestinian Rights', and one will look in vain for an equivalent division to protect Israelis; but this is to the point: there is no neutral transitional justice position.

${ }^{74}$ Thaif Deen, 'Palestinians Draw Line at Criminal Court', Asia Times Online, 8 April 2014, http://www.atimes. com/atimes/Middle_East/MID-01-080414.html (noting the criticism by Human Rights Watch of US objections to a renewed ICC application, and paraphrasing Congressional testimony by US UN Ambassador Samantha Power that "Washington is absolutely adamant that Palestine should not join the ICC because it poses a profound threat to Istael and would be devastating to the peace process'); Jeff Rathke, US State Department, Statement on ICC Decision (Press Statement), 16 January 2015, http://www.icc-cpi.int/iccdocs/PIDS/press/Palestine_A_12-3.pdf (reacting negatively to the Palestinian Authority's acceptance of ICC jurisdiction and noting that the US 'will continue to oppose actions against Israel at the ICC as counterproductive to the cause of peace').

${ }^{75}$ UN International Conference on Civil Society (n 70) 40 (discussing 'a global strategy to apply the International Convention on the Suppression and Punishment of the Crime of Apartheid to the situation in the occupied Palestinian territory'); BDS Movement, 'What is BDS', http://www.bdsmovement.net ('In 2005, Palestinian civil society issued a call for a campaign of boycotts, divestment and sanctions (BDS) against Israel until it complies with international law and Palestinian rights'); Chemi Shalev, 'West of Eden', Ha'aretz, 28 April 2014, http://www.haaretz.com/blogs/west-of-eden/1.587895 ("the term "apartheid" remains a highly toxic label for Israel ... [It] goes hand in hand with an international boycott campaign aimed at toppling its instigating regime'). ${ }^{76}$ Eitan Bronstein, 'They are Afraid: Israeli Jews and Palestinian Refugees', The Electronic Intifada, 3 June 2005, http:/electronicintifada.net/content/they-are-afraid-israeli-jews-and-palestinian-refugees/5615.

${ }^{77}$ UN International Conference on Civil Society (n 70), Annex I ('Call to Action: Realizing the inalienable rights of Palestinian people') 16, and see also 14 (noting comments of Na'eem Jeenah of the International Coordinating Network on Palestine on this proposal).

${ }^{78} \mathrm{cf}$ 'On World Refugee Day, PLO Wants Israel Held Accountable', WAFA, 19 June 2013, http://english.wafa.ps/ index.php?action=detail\&id=22661 (Hannan Ashrawi calling for accountability for al-Nakba and noting ' $[\mathrm{t}] \mathrm{his}$ process of victimization, exclusion and oppression continues until this day - Israel persists in its violations ... 
Even merely representing both views together as valid, as attempted by Zochrot, does not escape the political: through the BDS boycott effort, Palestinian activists have increasingly rejected initiatives that are consciously designed as balanced approaches to discussions or negotiations, on the grounds that balance is fictive under conditions of occupation.

Here we can see clearly that the peace process and transitional justice work are inextricably linked in this conflict - not merely tactically, but in foundational ways. Palestinian demands for a right of return - whether expressed as actual returns, symbolic returns, compensation or formal acknowledgement - and for recognition and repeal of the occupation are simultaneously claims that sound at the core of transitional justice as a discipline and one of the key sticking points in the general peace process. ${ }^{79}$ Indeed, within Palestinian frameworks, it is difficult to understand which part of the broader liberation struggle is not also part of a project of transitional justice, but this is difficult to square with Jewish frameworks about that same struggle.

This totalising quality is clearest on the Palestinian side, both because the experience of being occupied is more intense than that of being the occupier and because, lacking an adequate state structure, Palestinians have necessarily invested more governance in NGOs - indeed, to this limited extent it might be marginally more plausible to speak about a unified position within Palestinian civil society, if it were not for its evident and often violent rifts. ${ }^{80}$ However, even on the Israeli side, the entire project of Zionism, both its Herzlian and especially its post-Holocaust strains, can plausibly be understood as a claim for ameliorative or reparative justice. ${ }^{81}$ Yet, in turn, this plausible claim is entirely irreconcilable with the counterclaims of Palestinian justice. ${ }^{82}$

enjoying full immunity. The military occupation of the West Bank and Gaza that began in 1967 is an added form of oppression manifesting itself in the cruel captivity of the people and their land and resources ... The Palestine case ... remains an issue of indisputable justice and humanity').

${ }^{79}$ Ramona Wadi, 'Compensation to Palestinian Refugees and the Search for Palestine-Israel Peace', Middle East Monitor, 31 August 2013, https://www.middleeastmonitor.com/media-review/book-review/7164-compensationto-palestinian-refugees-and-the-search-for-palestine-israel-peace ('The consequences for Israel are striking and might even be interpreted as a preliminary step towards a dismantling of the foundations of the illegal state, as any form of compensation would imply acknowledging historical and moral responsibility for human rights violations against Palestinians'). On the interactions of restitution and a broader settlement, see generally Rex Brynen and Roula El-Rifai (eds), Compensation to Palestinian Refugees and the Search for Palestine-Israel Peace (Pluto Press 2013).

${ }^{80} \mathrm{~A}$ reminder, as well, of how problematic it can be to definitionally divide civil society and the state.

${ }^{81} \mathrm{cf}$ Naomi Darom, 'Why I Don't Stand for the Siren', Ha'aretz, 29 April 2014, http:/www.haaretz.com/opinion/. premium-1.587884 (discussing the politicisation of Holocaust remembrance); Carolina Landsmann, 'How to Traumatize a Nation of Children', Ha'aretz, 30 April 2014, http://www.haaretz.com/opinion/.premium-1. 588117 (criticising plans to introduce Holocaust studies into all classrooms). cf Almagor (Terror Victims Association), 'Goals', http:/al-magor.com/en/?page_id=19 (listing the following activities: emergency activism, social activities, legal action, information about terrorism, and memorialisation about terror victims - all typical of civil society - and noting that among its legal services 'Almagor petitions to the Supreme Court and provides representation for terror victims to demand harsh punishment for terrorists, expulsion of suicide terrorists' families, and demolition of terrorists' homes').

82 cf 'Israel Approves New Settlements in East Jerusalem for the First Time in 12 Years', Al Arabiya News, 19 December 2012, http://english.alarabiya.net/articles/2012/12/19/256008.html (discussing construction plans for Givat HaMatos, and quoting Palestinian negotiator Mohamed Shtayyeh that " $[\mathrm{t}] \mathrm{he}$ intensification of settlement activity [in east Jerusalem] and all the Israeli actions, from killings to arrests, are pushing us to accelerate our recourse to the International Criminal Court'). 


\subsection{No Common Goals}

This brings us to the final point: the analytical error in positing some notionally unified ideology of conflict resolution or transitional justice as a common goal of civil society. In Israel and Palestine, in fact, on both sides, civil society groups - narrowly or broadly defined - are instrumentalised to advance not a peace or justice agenda in the abstract, but a parochial definition of peace or justice that, seen from the other side, is an obstacle to resolution. ${ }^{83}$ Even when groups from one side or the other are actively playing the spoiler - whether against the other side or another faction on the same side ${ }^{84}$ - they are doing so in service of their own divergent vision of an acceptable settlement, and therefore also in the service of their own vision of transitional justice.

Indeed, there may not be any peace and justice efforts that can be analytically separated from the broader field of initiatives the purpose and effect of which is sometimes the very opposite of the bucolic received understanding of civil society. The range from vocal activism to violent action, the spectrum of activation, commitment and radicalism, must be understood as fraught but unbroken - as, at most, a kind of punctuated continuum.

\section{Consequences of an Impoverished Theoretical Perspective}

... and every community is established with a view to some good; for mankind always act in order to obtain that which they think good.

Aristotle, Politics ${ }^{85}$

Perhaps there can be a general theoretical perspective on civil society's involvement in transitional justice, but it requires a far more expansive framing than is commonly deployed; and failing to do so has consequences.

The heuristic reduction of civil society to a laundry list of progressive NGOs is understandable, given the Protean nature of the concept. The reduction, however, is too arbitrary, too

\footnotetext{
${ }^{83}$ Fourest ( $\mathrm{n} \mathrm{40)}$ 85-86 (noting that 'Israelis and Palestinians disagreed on their very nature and purpose [of P2P programmes]: Palestinians tended to use them as political platforms, while Israeli activists were motivated by social and cultural concerns'), and 92 (noting Palestinian groups' resistance to projects to normalise relations with Israelis while the occupation continues).

${ }^{84}$ Intra-Israeli difference is not only left-right, but temporal. The main lines of civil society have shifted over time, with "'enlightened" Jewish Israeli public opinion [evolving] in its attitude towards the morality of military action" from republican solidarity to 'disenchantment' to uncritical acceptance: Yoav Peled, 'From Oslo to Gaza: Israel's "Enlightened Public" and the Remilitarization of the Israeli-Palestinian Conflict' in Anna Stavrianakis, Jan Selby and Iraklis Oikonomou (eds), Militarism and International Relations: Political Economy, Security, Theory (Routledge 2012) 19. cf Jonathan Freedland, 'The Liberal Zionists' (2014) LXI(13) New York Review of Books 14 ('The squeezed nature of the liberal Zionists' position is hardly new, but in recent years the predicament has become more pronounced. The decline of the peace movement in Israel, along with the serial failure of the Israeli liberal party, has suggested a cause in retreat. In the United States, the liberal lions have come to resemble an endangered species').

${ }^{85}$ Aristotle (n 3). For 'community' another translation has '... and every partnership ...': Aristotle, The Politics, (Aristotle's Politics 1.1252a, Harris Rackham tr, 1957) Ch 1.
} 
under-theorised, too detached from its philosophical context to be helpful in understanding or strategising the role of civil society organisations generally or in relation to transitional justice. The concept's powerful if inchoate aspirations for the ethical quality of society have been hollowed out in its present, perfunctory invocation; its sacralisation has been accompanied by an emptying of meaning - becoming an ahistorical and unexamined good. ${ }^{86}$ From early modern models that understood civil society as an intermediating sphere between multiple conflicting preferences, we have moved to an implausibly monolithic vision: a common project of human rights, rule of law, progressive values and peace, as if these had a single shared meaning for all humanity. ${ }^{87}$

Analytical rigour consequently goes missing: it is difficult to ask meaningful questions about the relationship of civil society - or even NGOs - to conflict resolution or transitional justice if, owing to our impoverishing biases, we are looking only at some actors selected from a broader range. An overly narrow definition analyses the activity of groups 'working for' peace as inside the definition, that of groups outside the frame as the thing to be overcome - uncivil society, or threats to civil society. The result is a brittle, hagiographic, unsceptical view of civil society, and from this two opposite dangers arise.

The first is an overly optimistic estimation of the benefits that would accrue from supporting 'civil society's' efforts - since the thing is by definition good, fostering civil society must produce only good effects. Viewed another way, the second risk is of underestimating civil society's power: much of the literature bemoans the ineffectuality of civil society in the Israeli-Palestinian conflict, but this really means the marginality of civil society's progressive wing. An analytically accurate definition would recognise that civil society has, in many respects, proved to be remarkably powerful in shaping attitudes and policy about what constitutes peace and justice.

The effects of civil society on the transitional justice landscape are far more complex than first appears: the apparent failures of peace-building are also the successes of other agendas, and both are a result of civil society's actions - the actions, not only of committed if ineffectual coteries of good-doing leftists, but of the broader, illiberal civil society, which has effectively shifted the terms of contestation and dominated recent politics. ${ }^{88}$ This is visible only if we search the full range: examining just the 'goals and methods of civil society actors struggling for transitional justice $^{89}$ invites us to examine a distractingly narrow range of actors, and to ignore those

86 'Because its antecedents have not been adequately explored, civil society is often deployed in a thin, undertheorized and confusing fashion': Ehrenberg (n 6) x.

${ }^{87}$ cf Jessica Montell, 'Making Universalism Resonate Locally', Open Democracy, 23 August 2013, http:/www. opendemocracy.net/openglobalrights/jessica-montell/making-universalism-resonate-locally (discussing differing views of human rights among Israelis, including highly critical views of rights organisations as "unresponsive to local concerns, dismissive of traditional values and anti-religion').

${ }^{88} \mathrm{cf}$ Bob (n 32) 3 (noting that civil society's "'failures" are simultaneously victories for opponents').

${ }^{89}$ Text of the Call for Papers, Conference on Civil Society and Transitional Justice (n 36) (and noting earlier: 'From local grassroots organizations like the Mothers of the Plaza de Mayo in Argentina to international networks like the Coalition for the ICC, civil society organizations have been central in struggles for justice, truth and accountability across various contexts, while other civil society groups have been key actors in efforts of reconciliation, inter-community dialogue and conflict-transformation'). 
'struggling against transitional justice' - that is, struggling, quite successfully, for a different vision of justice.

I see no defensible arguments for limiting the definition of civil society to one's preferred politics - most commonly, in scholarship, to groups on the left. While there may be plausible arguments for excluding violent groups from definitions of civil society, no such limitation should be deployed in ways that distort our analytical understanding of which actors and actions in fact drive choices about peace and justice. Violent groups matter too, sometimes much more, and any robust theory of civil society must at least account for the interactions between communities that espouse and eschew violence.

In the same vein, it is not ultimately defensible to limit transitional justice - as an analytical category - to transitions from autocracy to democracy, rather than the other way round or between autocracies. We must study transitions, and claims about justice, in their fullness, even if our purpose is to advance a particular normative vision. ${ }^{90}$

For those for whom analysis divorced from moral commitments seems like a waste of time, there is still tactical value: taking one's ethics as given - a dubious proposition, if a common one - what organisational forms would actually help to achieve them? Are there strategies available that would not also work for one's opponents? These questions cannot be answered satisfactorily without first recognising what features friends share with foes; it would be like undertaking a study of military science by analysing only the tactics of one's allies. Thus, even if our purposes in thinking about civil society were entirely partisan, we should nonetheless - indeed, therefore, all the more - pay attention to analytical frames that cut across these unhelpful heuristics. ${ }^{91}$

It is good to recall that the word from Aristotle translated as 'civil', from which the idea of civil society descends, is cognate with the word 'political'. There is no neutral position: focusing on civil society's 'role' risks directing our attention towards notionally non-ideological, apolitical spaces, and away from the places in which struggle and compromise - in short, politics - occur. Recognising that there is no single, morally unified space of civil society should generate doubts about the usefulness of deliberative approaches, of seeking principled or neutral common ground as a basis for decision making in a world of intractable politics. ${ }^{92}$

None of this is to say that civil society does no good; Marx was completely wrong on this. On the contrary, a proper understanding of what we call civil society would conclude that, like any complex set of social actors, it sometimes does; but the real work done by civil society in

\footnotetext{
${ }^{90}$ Ruti Teitel, the originator of the field of transitional justice, defends just such a limitation, both in her writings and in conversations we had on the margins of the conference from which these papers arise. I greatly respect her body of work and her views more generally, but on this point I think she is defending a preference, not something probative. cf Guillaume Mouralis, 'The Invention of 'Transitional Justice' in the 1990s' in Liora Israël and Guillaume Mouralis (eds), Dealing with War and Dictatorships (Asser 2014) 83-100 (describing the rise of the concept and arguing that transitional justice is a political rather than an analytical category).

${ }^{91} \mathrm{cf} \mathrm{Bob} \mathrm{(n} \mathrm{8)} 209$ ('This is not to say that academics should abjure the quest for the good society or should remain neutral ... But ... these goals should be segregated from analysis - not least for the sake of achieving them').

${ }^{92} \mathrm{cf}$ Bob (n 32) 7 ('[C]ontending groups in democratic societies hold irreconcilable values. They see the world from incompatible perspectives ... There is limited room for the deliberation so cherished by idealists. Indeed, the combatants do not seek compromise ... Given these chasms, current theories emphasizing appropriateness, learning, and jawboning need to be supplemented').
} 
affecting peace and justice cannot properly be understood without locating it in a defensible theoretical and empirical framework. Imagining a narrow, morally unified civil society - one which, by definition, is working for some intuitive set of outcomes - risks skewing our analysis of what civil society can do and actually does in relation to conflict, west of the Jordan or anywhere. Civil society can help to clear the path to peace, or can throw up the principal obstacles to it - can simultaneously do both. In this it very much shares the ambiguous, multivalent profile of its classical conception and contemporary contrast: politics in the public sphere. 
